\title{
THE ADVANTAGES OF HELA CELLS FOR ISOLATION OF RHINOVIRUSES
}

\author{
Vera Strizova*, Pamela K. Brown, Beverley Head and Sylvia E. Reed \\ Medical Research Council Common Cold Unit, Harvard Hospital, Salisbury, \\ Wiltshire, SP2 $8 B W$
}

ISOLATION of rhinoviruses from clinical specimens is generally performed in semicontinuous lines of human embryo fibroblasts, such as WI-38 cells (Hayflick and Moorhead, 1961) or in primary cultures of human-embryo kidney. It is acknowledged that isolation may be difficult, that strains of fibroblasts vary in their sensitivity to rhinoviruses (Brown and Tyrrell, 1964), and that the development of a cytopathic effect (CPE) may be slow and uncertain (Olson, Willhight and Buescher, 1972). A HeLa cell line particularly sensitive to rhinoviruses was used by Hamparian, Leagus and Hilleman (1964) and a similar line by Fiala and Kenny (1966). Rhinovirus-sensitive HeLa cells have been used to study rhinovirus replication, for example by Stott and Heath (1970), and under suitable conditions at least 55 rhinovirus serotypes are known to produce plaques in them (Conant, Somerson and Hamparian, 1968; Fiala, 1968). Stott and Tyrrell (1968) suggested that HeLa cells could be used for the laboratory diagnosis of rhinovirus infection. For several years in this Unit, nasal washings from volunteers experimentally infected with rhinoviruses have been examined by inoculating in parallel, cultures of WI-38 cells and "rhinovirussensitive" HeLa cells, and higher isolation rates have almost always been achieved in the latter. These findings are reported here, together with the results of experiments on the comparative sensitivity of HeLa cells and two semicontinuous lines of diploid human embryo-lung (HEL) cells to three rhinovirus strains representing different serotypes. Two of the viruses were completely unadapted to tissue culture and the third had had only two passages in vitro.

\section{MATERIALS AND MethodS}

Studies on volunteers. Volunteers were housed and observed by methods standard in this Unit (Tyrrell, 1963). They were inoculated with rhinovirus in the course of various experimental studies. For re-isolation of virus, $10 \mathrm{ml}$ of Hanks' balanced salt solution was instilled in 1- or 2-ml amounts into each nostril alternately, and the discharged washing fluid was collected in a petri dish. The fluid was mixed with an equal volume of nutrient broth before storage at $-70^{\circ} \mathrm{C}$. The samples were tested for the presence of rhinovirus simultaneously in WI-38 and HeLa cells; serum designated HB was used in the tissue culture media throughout this part of the work (see below).

Cell cultures. Rhinovirus-sensitive HeLa cells, obtained in 1966 from Dr V. V. Hamparian, were grown and maintained as described by Stott and Tyrrell (1968). Cell stocks

Received 23 Jan. 1974; accepted 14 Feb. 1974.

* Visiting worker from Institute of Hygiene and Epidemiology, Prague.

J. MED. MICROBIOL. - VOL. 7 (1974)

433 
were subcultured once weekly. Cultures for virus titration were prepared in tubes or petri dishes and were used after two days.

The growth medium for the two lines of semicontinuous HEL cells, WI-38 and MRC-5 (Jacobs, Jones and Baillie, 1970) was Eagle's Basal Medium (BME) for diploid cells (Grand Island Biological Co.) with $0.11 \%(\mathrm{w} / \mathrm{v})$ sodium bicarbonate, 100 units per $\mathrm{ml}$ of penicillin, $100 \mu \mathrm{g}$ per $\mathrm{ml}$ of streptomycin and $10 \%$ bovine serum. Cell stocks were subcultured twice weekly, with a dilution of 1 in 2 at each subculture. Cell cultures for virus inoculation were grown in the same medium as that used for the stock cultures, and were maintained in similar medium containing $2 \%$ bovine serum.

Bovine sera were obtained from two sources. Harvard bovine serum (HB) was prepared from blood obtained at a local abattoir. Foetal calf serum (FC) was obtained from Flow Laboratories Ltd.

Viruses. Strains of the rhinovirus (RV) serotypes 1B, 2, 4, 9, 31 and 43 were used. The passage histories since their original isolation from "wild" colds were: RV1B, two passages in volunteers; RV2 as used for inoculation of volunteers, three or four previous passages in volunteers; RV2 as used for experiments in tissue culture, four passages in volunteers and two in HeLa cells; RV4, three passages in volunteers; RV9, four passages in volunteers interspersed with eight passages in human embryo-lung fibroblasts; RV31, one passage in human-embryo nasal-organ culture and one passage in volunteers; RV43, two passages in volunteers. Each serotype was identified with reference antiserum. Viruses for tissue culture experiments were prepared either as pools of nasal washings from volunteers infected with RV4 or RV31, or as fluid from tissue cultures infected with RV2, and were stored in portions at $-70^{\circ} \mathrm{C}$.

Virus titration methods. Tube cultures of HEL cells or HeLa cells were used for measurement of $50 \%$ tissue-culture infectious doses (TCD50) by the Karber method. Virus dilutions were $3 \cdot 2$-fold $(0.5 \log 10)$ and three tubes were inoculated with each dilution. Cultures were incubated on a roller drum at $33^{\circ} \mathrm{C}$ and were observed for characteristic CPE after 4 and 6 days in HeLa cells, or after 4, 7,10 and usually 14 days in HEL cells, or more frequently than this.

Plaque-forming units (PFU) of RV2 were estimated in HeLa cells by the method of Stott and Heath (1970) with $1 \log 10$ dilution steps and four petri dishes per dilution.

Experiments in tissue culture. Each week, HeLa cells and the two lines of HEL cells were subcultured in parallel with single batches of BME and serum, either HB or FC, as required for the various cell types, and cultures were prepared in tubes and petri dishes for virus titrations. The WI-38 cells were used from their 19th to 27th subcultures, and the MRC-5 cells from their 17th to 25 th subcultures.

When making comparative virus titrations in the three cell types a single set of virus dilutions, prepared from each virus pool, was used.

\section{RESULTS}

\section{Isolation of rhinoviruses from volunteers}

Table I shows the frequency of rhinovirus isolation from infected volunteers, in WI-38 cells and HeLa cells inoculated in parallel. This was almost always higher in HeLa cells, sometimes markedly so.

\section{Experiments in tissue culture}

The three viruses used for these experiments each produced a characteristic CPE in both HeLa and HEL cells. The M strains RV2 and RV31 produced a more rapidly spreading CPE than did the H strain RV4. The latter virus, when inoculated in low titres, produced recognisable foci of CPE, but in both HeLa 
cells and in fibroblasts the foci frequently did not progress to complete destruction of the cell sheet; however, a typical CPE was reproduced on subculture.

TABLE I

Comparison of the sensitivity of WI-38 cells and HeLa cells for the isolation of rhinoviruses from experimentally-infected volunteers

\begin{tabular}{l|ccc}
\hline Virus & $\begin{array}{c}\text { Number of } \\
\text { specimens } \\
\text { tested }\end{array}$ & $\overbrace{\text { WI-38 cells }}^{\text {Number of isolations made in }}$ & HeLa cells \\
\hline RV2 & 73 & 25 & 56 \\
RV2+RV43 & 22 & 16 & 20 \\
RV9 & 99 & 41 & 52 \\
RV1B & $4^{*}$ & 4 & 4 \\
\hline
\end{tabular}

* The mean infectivity titre of these specimens was $10^{1.2} \mathrm{TCD} 50$ per $\mathrm{ml}$ in WI-38 cells and 102.1 TCD50 per ml in HeLa cells.

With low-titre inocula of RV4 and RV31 a CPE usually appeared within 5 days in HeLa cells, but was often much more delayed in HEL cells.

Comparison of HeLa, WI-38 and MRC-5 cells. This was designed to compare the sensitivities of HeLa, WI-38 and MRC-5 cells, grown and maintained in media containing $\mathrm{HB}$, for infectivity titrations of the three viruses. Table II

TABLE II

Infectivity titres of three rhinoviruses pools measured in HeLa, WI-38 and MRC-5 cells, in five successive tests

\begin{tabular}{|c|c|c|c|c|c|c|}
\hline \multirow{2}{*}{ Virus } & \multirow{2}{*}{ Cell line } & \multicolumn{5}{|c|}{$\begin{array}{c}\text { Infectivity titres (log10 PFU per ml or TCD50 per ml)* } \\
\text { obtained in test number }\end{array}$} \\
\hline & & 1 & 2 & 3 & 4 & 5 \\
\hline RV2 & $\begin{array}{l}\text { HeLa } \\
\text { WI-38 } \\
\text { MRC-5 }\end{array}$ & $\begin{array}{l}7 \cdot 0 \\
4 \cdot 7 \\
\text { NT }\end{array}$ & $\begin{array}{l}6 \cdot 5 \\
4 \cdot 1 \\
3 \cdot 7\end{array}$ & $\begin{array}{l}6 \cdot 2 \\
3 \cdot 9 \\
4 \cdot 1\end{array}$ & $\begin{array}{l}6 \cdot 4 \\
3 \cdot 9 \\
3 \cdot 4\end{array}$ & $\begin{array}{l}6 \cdot 6 \\
4 \cdot 8 \\
4 \cdot 7\end{array}$ \\
\hline RV4 & $\begin{array}{l}\text { HeLa } \\
\text { WI-38 } \\
\text { MRC-5 }\end{array}$ & $\begin{array}{r}2.4 \\
<1.9 \\
\text { NT }\end{array}$ & $\begin{array}{r}2.7 \\
<1.4 \\
<1.4\end{array}$ & $\begin{array}{r}1.4 \\
<1.4 \\
<1.4\end{array}$ & $\begin{array}{r}2.6 \\
<1.4 \\
<1.4\end{array}$ & $\begin{array}{r}2.3 \\
0.9 \\
<0.9\end{array}$ \\
\hline RV31 & $\begin{array}{l}\text { HeLa } \\
\text { WI-38 } \\
\text { MRC-5 }\end{array}$ & $\begin{array}{l}\text { NT } \\
\text { NT } \\
\text { NT }\end{array}$ & $\begin{array}{l}\text { NT } \\
\text { NT } \\
\text { NT }\end{array}$ & $\begin{array}{r}2.4 \\
1.4 \\
<1.4\end{array}$ & $\begin{array}{r}2.9 \\
<1.4 \\
<1.4\end{array}$ & $\begin{array}{l}2.9 \\
1.6 \\
1.2\end{array}$ \\
\hline
\end{tabular}

* RV2 was titrated in HeLa cells as plaque-forming units per ml (PFU per ml); all other titres are expressed as $50 \%$ tissue-culture doses per $\mathrm{ml}$ (TCD50 per $\mathrm{ml}$ ). The titres given for RV2 in HeLa cells would be about $0.4 \log 10$ units lower if measured as TCD50 per ml.

$\mathrm{NT}=$ Not tested.

shows the results of five experiments set up in consecutive weeks. HeLa cells were the most sensitive for all three viruses. The mean titres of RV2 obtained from the five experiments were $10^{6 \cdot 54} \mathrm{PFU} / \mathrm{ml}$ in $\mathrm{HeLa}$ cells, $10^{4 \cdot 28 \mathrm{TCD} 50 / \mathrm{ml}}$ in WI-38 cells and 103.97TCD50/ml in MRC-5 cells (four tests only). It should 
be noted, however, that titres of RV2 in HeLa cells were measured by an enumerative (plaque) method, as $\mathrm{PFU} / \mathrm{ml}$, whereas all the other titrations were quantal (50\% endpoint) assays measuring TCD50/ml. The latter method theoretically, though not necessarily in practice, gives titres 1.44 times higher than plaque assays carried out in the same cells. To compare the sensitivity of the two techniques in HeLa cells under the conditions of our tests, a pool of RV2 was titrated five times by both methods. The plaque method actually gave infectivity titres (mean, 107.08 PFU per ml) which were about $0.4 \log 10$ units

TABLE III

Differences in infectivity titre obtained with three rhinoviruses, in several replicate experiments in parallel sublines of HeLa, WI-38 or MRC-5 cells, grown in medium containing either foetal or non-foetal bovine serum

\begin{tabular}{|c|c|c|c|}
\hline Cell line & Virus & $\begin{array}{c}\text { Differences* between the } \log 10 \text { TCD50 } \\
\text { values obtained in FC-containing and } \\
\text { HB-containing cultures }\end{array}$ & $\begin{array}{l}\text { Means of values } \\
\text { shown in preceding } \\
\text { column for each } \\
\text { cell line }\end{array}$ \\
\hline $\begin{array}{l}\text { HeLa } \\
\text { HeLa } \\
\text { HeLa }\end{array}$ & $\begin{array}{l}\text { RV2 } \\
\text { RV4 } \\
\text { RV31 }\end{array}$ & $\begin{array}{l}-0.5,+0.5,0 \\
0,0,+0.2 \\
+0.2,-0.5,-0.4\end{array}$ & -0.055 \\
\hline $\begin{array}{l}\text { WI-38 } \\
\text { WI-38 }\end{array}$ & $\begin{array}{l}\text { RV2 } \\
\text { RV4 }\end{array}$ & $\begin{array}{l}+0.5,0,+1.3 \\
+0.5,+0.5\end{array}$ & $+0.56(\mathrm{p}<0.1) \dagger$ \\
\hline $\begin{array}{l}\text { MRC-5 } \\
\text { MRC-5 } \\
\text { MRC-5 }\end{array}$ & $\begin{array}{l}\text { RV2 } \\
\text { RV4 } \\
\text { RV31 }\end{array}$ & $\begin{array}{l}+0.3,+0.2,-0.1,+0.7,+1.3 \\
>+0.1 \text { (in } 3 \text { experiments), }+0.8,>+0.3 \\
>+0.2\end{array}$ & $>+0.36(\mathrm{p}<0.02) \dagger$ \\
\hline
\end{tabular}

* The differences are those observed in replicate experiments.

$\dagger$ Significance of difference from zero ( $t$-test, method of paired comparisons).

$\mathbf{F C}=$ Foetal calf serum. $\mathrm{HB}=$ Harvard bovine serum (non-foetal).

(2.5-fold) higher than the $50 \%$ endpoint method (mean, $106.66 \mathrm{TCD} 50$ per $\mathrm{ml}$ ), presumably because of the more efficient virus absorption of the plaque technique. Therefore, if the titrations of RV2 in HeLa cells, recorded in table II as PFU per $\mathrm{ml}$, had instead been carried out by the $50 \%$ endpoint method, the readings obtained would probably have been about $0.4 \log 10$ units lower. However, the RV2 titres (TCD50 per ml) in the HEL cells were too far below the titres (actual PFU per ml or estimated TCD50 per ml) obtained in the HeLa cells for the differences to be attributable solely to the change in titration technique. The low sensitivity of HEL cells, compared with that of HeLa cells, was confirmed by the results obtained with RV4 and RV31; their titres, measured in TDC50 per $\mathrm{ml}$ in all three cell lines, were higher in HeLa cells than in either of the HEL cell lines. When RV4 and RV31 were used, a CPE often did not occur at all in HEL cells within the 2-week observation period, whereas in HeLa cells, a CPE was detectable within 5 days. The two HEL cell lines were similar in their sensitivity to the three rhinoviruses; the WI- 38 cells were possibly slightly more sensitive than the MRC-5 cells. There was no evidence that the passage level of the HEL cells influenced their virus sensitivity. 
Comparison of the effects of foetal and non-foetal bovine serum. In the preceding series of experiments all media contained non-foetal HB. A second series of experiments was carried out to compare the effects of foetal and non-foetal sera on the sensitivity of cells to RV infection. Preliminary passages of the three cell lines in media containing different batches of FC were necessary, to select serum which gave good cell growth. Each cell line was then maintained as two parallel sublines in medium containing either $\mathrm{HB}$ or $\mathrm{FC}$ for between one and seven subcultures. In a series of replicate experiments the three rhinoviruses were titrated in parallel in the three pairs of sublines. Table III shows the differences between the titres (TCD50) obtained with each virus in the parallel sublines. The MRC-5 and WI-38 cells maintained in medium containing FC generally gave slightly higher titres than in medium containing $\mathrm{HB}$, and the difference was statistically significant for MRC-5 cells, with which a larger number of tests was made. The kind of serum used had no obvious effect on the virus titres obtained with HeLa cells.

\section{DisCUSSION}

Our results show that a suitable line of HeLa cells can be more sensitive for detecting rhinoviruses in nasal secretions than the semicontinuous HEL cells customarily used for this purpose. Only six serotypes were used but it seems likely that the findings will apply generally. Although small inocula of poorlygrowing serotypes often produced only focal and non-progressive CPE in HeLa cells, the lesions were clearly recognisable and appeared more rapidly than in HEL cells.

Repeated experiments with nasal washings from infected volunteers, over a period of many months, indicated that HeLa cells were better than WI-38 cells for virus isolation when both lines were grown in medium containing nonfoetal bovine serum. Infectivity titrations with rhinoviruses which were minimally adapted or entirely unadapted to tissue culture confirmed that $\mathrm{HeLa}$ cells were more sensitive than WI-38 cells to "wild" viruses. Although the sensitivity of both WI-38 and MRC-5 cells increased somewhat when a suitable foetal bovine serum was used instead of non-foetal serum, HeLa cells remained superior. The sensitivity of HeLa cells was unaffected by the type of serum used, and it is interesting to speculate as to the mechanism by which non-foetal serum improved the sensitivity of one cell type but not another. The fact that both the HEL and HeLa cells grew equally well in media containing FC or HB suggests that a viral inhibitor active only in HEL cells may have been present in the nonfoetal serum.

\section{SUMMARY}

A sensitive line of HeLa cells was found to be better than two lines of diploid human embryo-lung (HEL) cells, WI-38 and MRC-5, for the isolation of several serotypes of rhinovirus from experimentally-infected volunteers. Comparative infectivity titrations of three rhinoviruses which were either unadapted or only partly adapted to tissue culture confirmed the greater sensitivity of the HeLa cells. The substitution of foetal calf serum for non-foetal bovine 
serum in the tissue culture medium slightly enhanced the sensitivity of the HEL cells to rhinoviruses but had no such effect on HeLa cells; HeLa cells nevertheless remained more sensitive than HEL cells. The line of HeLa cells studied merits more general use for the isolation of rhinoviruses from clinical specimens.

One of us (V.S.) held a Fellowship from the World Health Organisation. We are grateful to Dr D. A. J. Tyrrell for helpful comments.

\section{REFERENCE}

Brown, P. K. ANd Tyrrell, D. A. J. 1964. Experiments on the sensitivity of strains of human fibroblasts to infection with rhinoviruses. Br. J. exp. Path., 45, 571 .

Conant, R. M., Somerson, N. L. ANd Hamparian, V. V. 1968. Plaque formation by rhinoviruses. Proc. Soc. exp. Biol. Med., 128, 51.

Fiala, M. 1968. Plaque formation by 55 rhinovirus serotypes. Appl. Microbiol., 16, 1445.

Fiala, M. AND KenNy, G. E. 1966. Enhancement of rhinovirus plaque formation in human heteroploid cell cultures by magnesium and calcium. J. Bact., 92, 1710.

Hamparian, V. V., Leagus, M. B. and Hilleman, M. R. 1964 . Additional rhinovirus serotypes. Proc. Soc. exp. Biol. Med., 116, 976.

HaYflick, L. AND MOORHEAD, P. S. 1961. The serial cultivation of human diploid cell strains. Exp. Cell Res., 25, 585.

JACOBS, J. P., Jones, C. M. AND Baillie, J. P. 1970. Characteristics of a human diploid cell designated MRC-5. Nature, Lond., 227, 168.

Olson, L. C., Willhight, M. AND BuESCHER, E. L. 1972. Recovery and characterization of non-cytopathogenic rhinoviruses. J. gen. Virol., 17, 237.

Stott, E. J. AND Heath, G. F. 1970. Factors affecting the growth of rhinovirus 2 in suspension cultures of L132 cells. J. gen. Virol., 6, 15 .

Stott, E. J. AND TYRRELl, D. A. J. 1968. Some improved techniques for the study of rhinoviruses using HeLa cells. Archiv. ges. Virusforsch., 23, 236.

Tyrrell, D. A. J. 1963. The use of volunteers. Am. Rev. resp. Dis., 88, 128. 